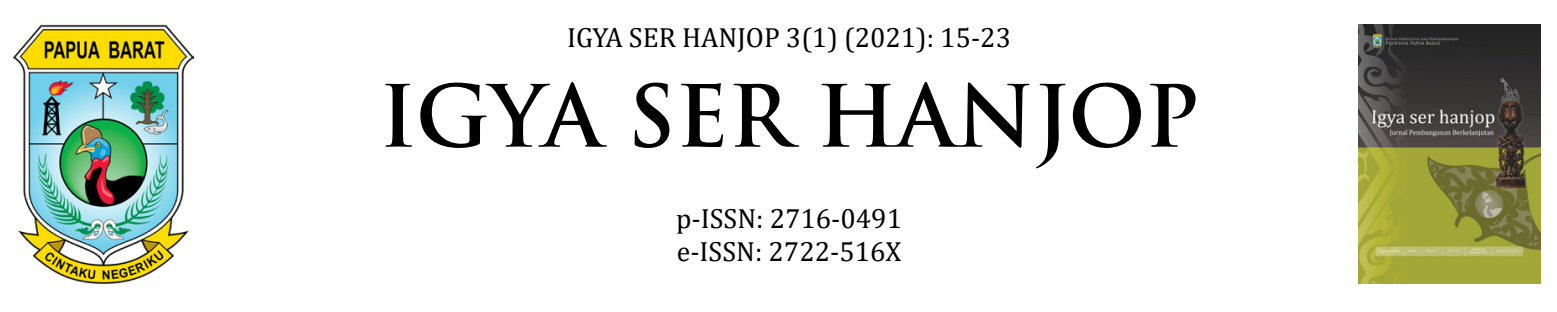

\title{
Remote Audit Sebagai Prosedur Audit Alternatif InSPEKTORAT DAERAH Provinsi PAPUA BARAT PADA MASA PANDEMI Covid-19
}

\section{REMOTE AUDIt AS AN ALTERNATIVE FOR AUDITOR of WEST PAPUA PROVINCE'S REgIONAL INSPECTORATE DURING THE COVID-19 PANDEMIC}

\author{
Lila Fitriana ${ }^{1 *}$, Maman Permana ${ }^{2}$ \\ ${ }^{1}$ Inspektorat Daerah Provinsi Papua Barat \\ Jl. Brig. Jend. Mar. (Purn) Abraham O. Atururi, Kompl. Perkantoran Arfai, Manokwari Papua Barat, 98315 \\ ${ }^{2}$ Badan Narkotika Nasional Provinsi Papua Barat \\ Jl. Esau Sesa Manokwari, Papua Barat, Indonesia, 98312
}

Dikirim: 26 Maret 2021; Setujui: 20 Mei 2021; Diterbitkan : 20 Juni 2021

DOI: 10.47039/ish.3.2021.15-23

\begin{abstract}
Inti Sari
COVID-19 mengakibatkan audit tradisional atau audit tatap muka beresiko untuk dilaksanakan, sehingga diperlukan suatu prosedur audit alternatif yang dapat digunakan selama masa pendemi. Saat ini, Inspektorat Daerah Provinsi Papua Barat belum memiliki suatu standar maupun prosedur untuk melakukan audit di masa pandemi. Penelitian ini bertujuan untuk menentukan prosedur audit alternatif yang dapat digunakan oleh Inspektorat Daerah Provinsi Papua Barat. Metode penelitian yang digunakan adalah kualitatif deskriptif. Pengambilan data dilakukan melalui observasi, wawancara dan studi literatur. Hasil penelitian menunjukkan Inspektorat Daerah Provinsi Papua Barat pada tahun 2020 melaksanakan 21 dari 39 kegiatan audit dalam Program Kerja Pengawasan Tahunan, baik sebelum dan selama masa pandemi dengan menggunakan metode tatap muka. Hasil penelitian menunjukkan bahwa remote audit dapat digunakan pada setiap tahap audit mulai dari entry meeting, document review, kunjungan lapangan, interview, dan closing meeting. Hal yang harus dipersiapkan dalam pelaksanaan remote audit adalah kesiapan teknologi informasi dan keterampilan auditor maupun yang diaudit dalam menggunakan peralatan teknologi informasi.
\end{abstract}

Kata Kunci: covid-19, pandemi, auditor, audit, remote audit.

\begin{abstract}
The COVID-19 has resulted in risky traditional audits or face-to-face audits to being carried out, therefore an alternative procedure is needed. Currently, the Regional Inspectorate of West Papua Province does not have a standard or procedure for conducting audits during the pandemic. This study aims to determine alternative audit procedures that can be used during the pandemic. The research used descriptive qualitative method, data were collected by observation, interviews, and literature studies. In 2020, the Inspectorate Office, conducted 21 of 39 audits in the Annual Audit Work Program before and during the pandemic by using the face-to-face audit method. The results indicated that remote audit can be used at every stage of the audit, starting from entry meetings, document review, field visits, interviews, and closing meetings. However, to be implemented successfully are the readiness of information technology and capacity of auditors and auditee.
\end{abstract}

Keywords: covid-19, pandemic, auditor, audit, remote audit.

\footnotetext{
* Korespondensi Penulis

Tlp : :6285342006398

Email : lilafitriana15@gmail.com
}

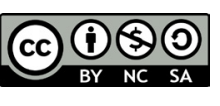

(C) 2020 Lila Fitriana, Maman Permana.

Ciptaan disebarluaskan di bawah Lisensi Creative

Commons Atribusi NonKomersial-Berbagi Serupa
15 


\section{Pendahuluan}

Pada saat ini dunia sedang mengalami pandemi global Corona Virus Disease (COVID-19). Menurut WHO (2020) jumlah kasus terus meningkat. Pada 12 November 2020 tercatat jumlah kasus terkonfirmasi di dunia sebanyak 51,8 juta jiwa dan di Indonesia sebanyak 448.118 ribu jiwa. Sedangkan di Papua Barat menurut Satuan Tugas (Satgas) COVID-19 Papua Barat jumlah kasus terkonfirmasi sebanyak 4.615 jiwa.

Pandemi COVID-19 telah menyebabkan perubahan pola hidup dan pola kerja yang harus mengikuti protokol kesehatan untuk mencegah terjadinya penyebaran COVID-19 atau disebut dengan adaptasi kebiasaan baru (new normal). Perubahan pola kerja di masa pandemi tersebut berlaku juga di lingkungan instansi pemerintah. Berdasarkan Surat Edaran Menteri Pendayagunaan Aparatur Negara Nomor 58 Tahun 2020 tanggal 29 Mei 2020, Aparatur Sipil Negara (ASN) tetap dituntut untuk menjalankan tugas dan fungsi secara produktif dengan menerapkan Work From Office (WFO) dan Work From Home (WFH) dengan komposisi menyesuaikan status risiko daerah bersangkutan.

COVID-19 juga berdampak terhadap proses audit yang dilaksanakan oleh auditor pada instansi pengawasan. Himbauan untuk melakukan WFH dan pemberlakuan pembatasan sosial berskala besar berimbas pada pembatasan akses dan perjalanan serta ketersediaan auditor maupun auditee.

Auditor harus tetap menjaga kualitas audit serta memperoleh bukti audit yang cukup dan tepat untuk mendukung opini audit (Castka et al., 2020). Institut Akuntan Publik Indonesia pada 2020 melaporkan bahwa respon auditor yang diharapkan di masa pandemi COVID-19 melakukan modifikasi atas prosedur pengumpulan bukti audit, proses identifikasi, penilaian risiko, serta mengubah prosedur audit yang direncanakan atau melakukan prosedur alternatif atau prosedur audit lanjutan yang tepat (Tanudiredja et al., 2020). Auditor juga perlu melakukan perubahan yang relevan, mengeksplorasi prosedur audit alternatif untuk menemukan alternatif lain sebagai pengganti proses audit tradisional.

Inspektorat Daerah Provinsi Papua Barat merupakan salah satu Aparat Pengawas Intern
Pemerintah (APIP) harus tetap melakukan audit di masa pandemi dengan tetap mematuhi protokol kesehatan. Namun saat ini kantor Inspektorat Papua Barat belum memiliki standar atau prosedur audit alternatif di masa pandemi. Berdasarkan hal tersebut, perlu adanya prosedur audit alternatif yang tepat dan dapat digunakan masa pandemi COVID-19. Penelitian ini bertujuan untuk mengetahui prosedur audit alternatif yang dapat digunakan Kantor Inspektorat di masa pandemi COVID-19.

\section{METODE}

Salah satu prosedur audit alternatif yang bisa dilaksanakan selama masa pandemi COVID-19 adalah audit jarak jauh atau remote audit. The Institute of Internal Auditors/ IIA (2020) mendefinisikan remote audit sebagai audit jarak jauh yang mengacu pada penggunaan teknologi dalam mengumpulkan informasi, mewawancarai auditee, dan prosedur audit lainnya, ketika metode tatap muka tidak dapat dilakukan. Remote audit bukan merupakan hal yang baru, International Organization of Standardization (ISO) pada tahun 2018 telah menetapkan ISO 19011 yang di dalamnya mengatur audit on-site dan remote audit. Selanjutnya pada tahun 2020 ISO menerbitkan pedoman remote audit sesuai Auditing Practices Group Guidance on Remote Audits (ISO 9001).

Maudica et al. (2020), menyebutkan bahwa pandemi COVID-19 membatasi auditor untuk melaksanakan audit di lapangan, akan tetapi auditor tetap dapat melaksanakan audit dengan mengumpulkan data-data yang relevan dan melakukan peninjauan temuan secara daring atau online. Sedangkan Efendi (2020) menyebutkan bahwa kegiatan audit secara online mengharuskan APIP untuk meningkatan kompetensi auditor dalam menggunakan teknologi informasi dan dukungan anggaran untuk pembangunan infrastruktur teknologi informasi. Selain itu muncul resiko baru akibat penggunaan komputer dan memerlukan waktu untuk penyesuaian terhadap proses audit secara online.

Penelitian ini menggunakan metode deskriptif kualitatif. Nazir (2003) menyebutkan bahwa metode deskriptif merupakan suatu metode dalam meneliti status kelompok manusia, suatu objek, suatu set kondisi, 
suatu sistem pemikiran, ataupun suatu kelas peristiwa pada masa sekarang. Sedangkan Moleong (1989) mendefinisikan metode kualitatif sebagai prosedur penelitian yang menghasilkan data deskriptif berupa katakata tertulis atau lisan dari orang-orang dan perilaku yang diamati.

Pengambilan data dilakukan melalui studi literatur, observasi dan wawancara. Teknik observasi yang dilakukan yaitu observasi partisipatif dimana peneliti mengamati dan berpartisipasi langsung terhadap apa yang diteliti. Teknik pengambilan data dilakukan secara sengaja (purposive sampling) melalui wawancara terhadap partisipan yang mengetahui topik penelitian. Partisipan berjumlah 11 orang terdiri dari 4 orang Inspektur Pembantu Wilayah I, II, III, dan IV pada Inspektorat Daerah, 2 orang auditor pada Inspektorat Daerah, dan 5 orang auditee dari organisasi perangkat daerah di lingkungan Pemerintah Provinsi Papua Barat. Studi literatur dilakukan dengan menghimpun informasi yang relevan terkait topik yang diteliti baik dari catatan, dokumen pengawasan, laporan penelitian, peraturan-peraturan, dan sumber lainnya.

\section{HaSil dAN PEMbahasan}

Hasil penelusuran dokumen dan wawancara, pada PKPT Inspektorat Daerah Provinsi Papua Barat Tahun 2020 terdapat 39 kegiatan pengawasan yang harus dilaksanakan selama tahun 2020, tetapi 18 kegiatan tidak dapat dilaksanakan (Tabel 1).

Tabel 1.

Program Kerja Pengawasan Tahunan Inspektorat Daerah Provinsi Papua Barat

\begin{tabular}{|c|c|c|c|c|}
\hline No & Kegiatan & Lokasi & Auditee & Ket \\
\hline 1 & Opname kas dan persediaan & Manokwari & 48 OPD & Terlaksana \\
\hline 2 & Pemeriksaan disiplin ASN & Manokwari & 48 OPD & Terlaksana Sebagian \\
\hline 3 & Review HPS & Manokwari & Pemprov PB & Tidak \\
\hline 4 & Pemeriksaan reguler/kinerja Semester I & Manokwari & 48 OPD & Terlaksana Sebagian \\
\hline 5 & Review RKAKL & Manokwari & Tentatif & Terlaksana \\
\hline 6 & Probity Audit & Manokwari & Pemprov PB & Tidak \\
\hline 7 & Review LKPD 2019 & Manokwari & Pemprov PB & Terlaksana \\
\hline 8 & Review LKIP Pemprov PB & Manokwari & Pemprov PB & Terlaksana \\
\hline 9 & $\begin{array}{l}\text { Monitoring Pelaksanaan Renaksi } \\
\text { Pencegahan Korupsi TW I }\end{array}$ & Manokwari & Pemprov PB & Terlaksana \\
\hline 10 & $\begin{array}{l}\text { Review PBJ dan Serapan Anggaran } \\
\text { Triwulan I }\end{array}$ & Manokwari & Pemprov PB & Tidak \\
\hline 11 & Audit Kepatuhan Pengelolaan Keuangan & Manokwari & 48 OPD & Tidak \\
\hline 12 & Sosialisasi Manajemen Risiko OPD & Manokwari & 8 OPD & Tidak \\
\hline 13 & Sosialisasi Pengendalian Gratifikasi OPD & Manokwari & 8 OPD & Tidak \\
\hline 14 & Monitoring Pelaksanaan Program RB & Manokwari & Pemprov PB & Terlaksana \\
\hline 15 & PMPRB PB & Manokwari & 8 OPD & Terlaksana \\
\hline 16 & Draft Review RPJMD 2017-2022 & Manokwari & Pemprov PB & Tidak \\
\hline 17 & Draft Review RKPD 2021 & Manokwari & Pemprov PB & Terlaksana \\
\hline 18 & $\begin{array}{l}\text { Monitoring Pelaksanaan Renaksi } \\
\text { Pencegahan Korupsi TW II }\end{array}$ & Manokwari & Pemprov PB & Terlaksana \\
\hline 19 & Review RKA APBD-P 2020 & Manokwari & Pemprov PB & Tidak \\
\hline 20 & Evaluasi SAKIP SKPD & Manokwari & 48 OPD & Terlaksana \\
\hline 21 & $\begin{array}{l}\text { Review PBJ dan Serapan Anggaran } \\
\text { Triwulan II }\end{array}$ & Manokwari & 48 OPD & Tidak \\
\hline 22 & Evaluasi LKIP Kab/Kota & Kab/Kota & $3 \mathrm{Kab} /$ Kota & Tidak \\
\hline
\end{tabular}




\begin{tabular}{|c|c|c|c|c|}
\hline No & Kegiatan & Lokasi & Auditee & Ket \\
\hline 23 & Evaluasi Implementasi SPIP OPD & Manokwari & 48 OPD & Tidak \\
\hline 24 & EKPPD & Kab/Kota & $13 \mathrm{Kab} /$ Kota & Terlaksana \\
\hline 25 & $\begin{array}{l}\text { Pemeriksaan Akhir Masa Jabatan Bupati } \\
\text { Pegunungan ( } 9 \mathrm{Kab})\end{array}$ & Kab/Kota & $9 \mathrm{Kab}$ & Tidak \\
\hline 26 & $\begin{array}{l}\text { Review PBJ dan Serapan Anggaran } \\
\text { Triwulan III }\end{array}$ & Manokwari & 48 OPD & Terlaksana \\
\hline 27 & $\begin{array}{l}\text { Monitoring Pelaksanaan Renaksi } \\
\text { Pencegahan Korupsi TW III }\end{array}$ & Manokwari & Pemprov PB & Terlaksana \\
\hline 28 & Pemeriksaan regular/kinerja Semester II & Manokwari & 48 OPD & Tidak \\
\hline 29 & $\begin{array}{l}\text { Review PBJ dan Serapan Anggaran } \\
\text { Triwulan IV }\end{array}$ & Manokwari & 48 OPD & Tidak \\
\hline 30 & $\begin{array}{l}\text { Monitoring Pelaksanaan Renaksi } \\
\text { Pencegahan Korupsi TW IV }\end{array}$ & Manokwari & Pemprov PB & Tidak \\
\hline 31 & Sosialisasi SPIP OPD & Manokwari & 48 OPD & Tidak \\
\hline 32 & Review RKA APBD 2021 & Manokwari & Pemprov PB & Tidak \\
\hline 33 & Penanganan Pengaduan Masyarakat & Tentatif & Tentatif & Terlaksana \\
\hline 34 & Optimalisasi Pajak Daerah & Manokwari & Bappenda & Tidak \\
\hline 35 & Whistle Blowing System & Tentatif & Tentatif & Terlaksana \\
\hline 36 & Evaluasi Kinerja BUMD & Manokwari & PT. Padoma & Terlaksana \\
\hline 37 & $\begin{array}{l}\text { Audit Tujuan Tertentu Permintaan } \\
\text { Pimpinan }\end{array}$ & Tentatif & Tentatif & Terlaksana \\
\hline 38 & Audit Pelanggaran Kode Etik ASN & Tentatif & Tentatif & Terlaksana \\
\hline 39 & Audit Investigatif & Tentatif & Tentatif & Terlaksana \\
\hline
\end{tabular}

Sumber: Inspektorat Daerah Provinsi Papua Barat, 2020 (telah diolah kembali)

Kegiatan pengawasan ada yang dilaksanakan sebelum masa pandemi dan ada yang selama masa pandemi. Kegiatan pengawasan yang dilaksanakan dalam masa pandemi menggunakan model audit tradisional atau tatap muka namun dengan memperhatikan protokol kesehatan seperti menggunakan masker dan menjaga jarak.

Pelaksanaan audit tatap muka pada masa pandemi COVID-19 sangat beresiko dan berbahaya baik bagi auditor maupun auditee. Berdasarkan keterangan Sekretaris Inspektorat Daerah Provinsi Papua Barat terdapat 6 orang Auditor Inspektorat Daerah Papua Barat yang telah terkonfirmasi positif COVID-19 selama tahun 2020.

\section{A. Identifikasi Risiko dan Peluang Penggunaan Remote Audit}

Remote audit dapat menjadi prosedur audit alternatif yang digunakan untuk audit di masa pandemi COVID-19 (ISO, 2020;
Litzenberg \& Ramirez, 2020). Remote audit memiliki kelebihan antara lain mengurangi biaya perjalanan, memperluas cakupan audit, pengumpulan data dan dokumen lebih cepat (Iskandar, 2020; Litzenberg \& Ramirez, 2020). Sedangkan kekurangannya, adalah pengamatan secara langsung tidak dapat digantikan, menyulitkan hubungan dengan auditee, kurangnya interaksi personal sehingga membuka peluang terjadinya fraud (Iskandar, 2020; Litzenberg \& Ramirez, 2020).

Tabel 2 menunjukkan berbagai kelebihan dari remote audit, namun terdapat juga berbagai resiko yang mungkin terjadi pada pelaksanaan remote audit. Selanjutnya perlu dilakukan persiapan untuk meminimalisir terjadinya resiko dalam pelaksanaan remote audit antara lain:

1. Auditee dan tim audit harus memastikan persyaratan teknologi yang tepat untuk audit virtual yang mencakup hal-hal seperti: 
Tabel 2.

Identifikasi Risiko dan Peluang Remote Audit (ISO/2020)

\begin{tabular}{|c|c|c|c|}
\hline $\begin{array}{l}\text { Penggunan } \\
\text { Teknologi } \\
\text { Informasi dan } \\
\text { Komunikasi }\end{array}$ & $\begin{array}{c}\text { Potensi } \\
\text { Penggunaan }\end{array}$ & Risiko & Peluang \\
\hline \multirow[t]{2}{*}{$\begin{array}{l}\text { Video Call: Skype, } \\
\text { Webex, Zoom }\end{array}$} & $\begin{array}{l}\text { Wawancara } \\
\text { Tinjauan lapangan }\end{array}$ & $\begin{array}{l}\text { - Pelanggaran keamanan dan keraha- } \\
\text { siaan; } \\
\text { - Perbedaan zona waktu; } \\
\text { - Otentifikasi personal; } \\
\text { - Rendahnya kualitas komunikasi; } \\
\text { - Auditor tidak dapat mengamati } \\
\text { keadaan organisasi secara mendalam }\end{array}$ & $\begin{array}{l}\text { - Wawancara bisa dimana saja } \\
\text { - Opening dan closing meeting } \\
\text { di beberapa tempat } \\
\text { - Mengurangi biaya perjalanan } \\
\text { - Cakupan geografis lebih luas }\end{array}$ \\
\hline & Document review & $\begin{array}{l}\text { - Pelanggaran keamanan dan keraha- } \\
\text { siaan; } \\
\text { - Kesulitan pengumpulan dokumen } \\
\text { - Membutuhkan waktu lebih lama; } \\
\text { - Potensi manipulasi data } \\
\text { - Kurangnya interaksi dengan auditee } \\
\text { - Kualitas informasi yang dikumpulkan } \\
\text { berkurang }\end{array}$ & $\begin{array}{l}\text { - Document review di tempat } \\
\text { yang tidak dapat didatangi; } \\
\text { - Bagus untuk multi site teru- } \\
\text { tama lokasi terpencil } \\
\text { - Mengurangi biaya perjalanan } \\
\text { dan dampak lingkungan }\end{array}$ \\
\hline Survey, Aplikasi & $\begin{array}{l}\text { Mengisi ceklis dan } \\
\text { kuisioner }\end{array}$ & $\begin{array}{l}\text { - Jaminan otentifikasi } \\
\text { - Persiapan dokumen ceklist dan jawa- } \\
\text { ban responden membutuhkan biaya }\end{array}$ & $\begin{array}{l}\text { - Pengetahuan tentang organi- } \\
\text { sasi lebih baik } \\
\text { - persiapan audit lebih lama } \\
\text { - tambahan waktu untuk } \\
\text { menyiapkan kunjungan } \\
\text { lapangan }\end{array}$ \\
\hline $\begin{array}{l}\text { Data and docu- } \\
\text { ment review }\end{array}$ & $\begin{array}{l}\text { Melihat catatan, } \\
\text { prosedur, alur ker- } \\
\text { ja dan lain-lain }\end{array}$ & $\begin{array}{l}\text { - Keamanan dan kerahasian } \\
\text { - Sulitnya prosedur melihat dokumen } \\
\text { - Membutuhkan waktu lebih lama } \\
\text { - Potensi manipulasi data } \\
\text { - Kurangnya interaksi dengan auditee } \\
\text { - Transparansi } \\
\text { - kehilangan persepsi apa yang diaudit }\end{array}$ & $\begin{array}{l}\text { - Waktu yang fleksibel } \\
\text { - Lebih baik untuk mengek- } \\
\text { splorasi informasi lebih jauh }\end{array}$ \\
\hline $\begin{array}{l}\text { Video } \\
\text { (drone, live } \\
\text { streaming) }\end{array}$ & $\begin{array}{l}\text { Monitoring lokasi } \\
\text { berbahaya } \\
\text { Kunjungan lapa- } \\
\text { ngan } \\
\text { Melihat proses } \\
\text { berisiko tinggi }\end{array}$ & $\begin{array}{l}\text { - Risiko penggunaan dan keberadaan } \\
\text { peralatan } \\
\text { - Kualitas gambar } \\
\text { - Kebenaran data }\end{array}$ & $\begin{array}{l}\text { - Memudahkan monitoring } \\
\text { tugas beresiko; } \\
\text { - Ideal untuk audit yang tidak } \\
\text { membutuhkan kehadiran tim } \\
\text { - Baik untuk kegiatan outdoor }\end{array}$ \\
\hline $\begin{array}{l}\text { Video } \\
\text { (CCTV, rekaman } \\
\text { video) }\end{array}$ & $\begin{array}{l}\text { Monitoring kegia- } \\
\text { tan yang tidak se- } \\
\text { dang berlangsung } \\
\text { Proses Video } \\
\text { Rekaman call } \\
\text { center } \\
\text { Rekaman webinar }\end{array}$ & $\begin{array}{l}\text { - Keamanan dan kerahasian } \\
\text { - Kualitas gambar; } \\
\text { - Kebenaran data }\end{array}$ & $\begin{array}{l}\text { - Lebih menguntungkan } \\
\text { - Kemungkinan mengamati } \\
\text { tempat dan fasilitas sulit } \\
\text { dijangkau dan menambah } \\
\text { sampel } \\
\text { - Jika catatan elektronik } \\
\text { memiliki data sensitif perlu } \\
\text { dipertimbangkan untuk pen- } \\
\text { injauan lapangan }\end{array}$ \\
\hline
\end{tabular}

Sumber: ISO, 2020 (telah diolah kembali) 
a. Memastikan tim audit menggunakan protokol akses jarak jauh yang disepakati, termasuk perangkat yang dibutuhkan, perangkat lunak, dan lainlain;

b. Melakukan pemeriksaan teknis sebelum pelaksanaan audit;

c. Memastikan adanya contingency plan yang sudah dikomunikasikan dengan auditee, misalnya gangguan akses, penggunaan teknologi alternatif dan kemungkinan penambahan waktu jika diperlukan.
2. Kompetensi auditor berupa keterampilan teknis dalam menggunakan peralatan elektronik dan adanya pengalaman dalam melaksanakan rapat secara virtual.

\section{B. Prosedur Audit Menggunakan Remote Audit}

Berdasarkan hasil identifikasi risiko dan peluang (ISO, 2020), dan tahapan remote auditing (Litzenberg \& Ramirez, 2020; Setianto, 2020) disarankan kegiatan audit sebagaimana program kerja pengawasan tahunan (PKPT) Tahun 2020 dilakukan secara remote, sebagaimana disajikan pada Tabel 3.

Tabel 3.

Identifikasi Tahapan Audit Berdasarkan PKPT secara Remote

\begin{tabular}{|c|c|c|c|c|c|c|}
\hline \multirow[b]{2}{*}{ No. } & \multirow[b]{2}{*}{ Kegiatan } & \multicolumn{5}{|c|}{ Tahapan Audit } \\
\hline & & $\begin{array}{c}\text { Entry } \\
\text { meeting } \\
\text { (Video Live } \\
\text { streaming) }\end{array}$ & $\begin{array}{c}\text { Kajian } \\
\text { dokumen } \\
\text { (Upload \& } \\
\text { review) }\end{array}$ & $\begin{array}{c}\text { Kunjungn } \\
\text { lapangan (Live } \\
\text { Streaming/ } \\
\text { Video Record) }\end{array}$ & $\begin{array}{l}\text { Interview } \\
\text { (Video Call) }\end{array}$ & $\begin{array}{c}\text { Closing } \\
\text { Meeting } \\
\text { (Video Live } \\
\text { streaming) }\end{array}$ \\
\hline 1 & $\begin{array}{l}\text { Opname kas dan } \\
\text { persediaan }\end{array}$ & v & $v$ & $v$ & $v$ & $v$ \\
\hline 2 & Pemeriksaan disiplin ASN & v & $v$ & - & $v$ & v \\
\hline 3 & Review HPS & $v$ & v & - & v & v \\
\hline 4 & $\begin{array}{l}\text { Pemeriksaan reguler/ } \\
\text { kinerja Semester I }\end{array}$ & $v$ & $v$ & v & v & $v$ \\
\hline 5 & Review RKAKL & v & $v$ & - & $v$ & $v$ \\
\hline 6 & Probity Audit & $v$ & $v$ & $v$ & v & $v$ \\
\hline 7 & Review LKPD 2019 & $v$ & $v$ & - & $v$ & $v$ \\
\hline 8 & Review LKIP Pemprov PB & v & $\mathrm{v}$ & - & v & $v$ \\
\hline 9 & $\begin{array}{l}\text { Monitoring Pelaksanaan } \\
\text { Renaksi Pencegahan } \\
\text { Korupsi TW I }\end{array}$ & v & $v$ & - & $v$ & $v$ \\
\hline 10 & $\begin{array}{l}\text { Review PBJ dan Serapan } \\
\text { Anggaran Triwulan I }\end{array}$ & $v$ & $v$ & - & $v$ & $v$ \\
\hline 11 & $\begin{array}{l}\text { Audit Kepatuhan } \\
\text { Pengelolaan Keuangan }\end{array}$ & $v$ & $v$ & $v$ & $v$ & $v$ \\
\hline 12 & $\begin{array}{l}\text { Sosialisasi Manajemen } \\
\text { Risiko OPD }\end{array}$ & - & - & - & - & - \\
\hline 13 & $\begin{array}{l}\text { Sosialisasi Pengendalian } \\
\text { Gratifikasi OPD }\end{array}$ & - & - & - & - & - \\
\hline 14 & $\begin{array}{l}\text { Monitoring Pelaksanaan } \\
\text { Program RB }\end{array}$ & $v$ & $v$ & $v$ & $v$ & $v$ \\
\hline
\end{tabular}




\begin{tabular}{|c|c|c|c|c|c|c|}
\hline \multirow[b]{2}{*}{ No. } & \multirow[b]{2}{*}{ Kegiatan } & \multicolumn{5}{|c|}{ Tahapan Audit } \\
\hline & & $\begin{array}{c}\text { Entry } \\
\text { meeting } \\
\text { (Video Live } \\
\text { streaming) }\end{array}$ & $\begin{array}{c}\text { Kajian } \\
\text { dokumen } \\
\text { (Upload \& } \\
\text { review) }\end{array}$ & $\begin{array}{c}\text { Kunjungn } \\
\text { lapangan (Live } \\
\text { Streaming/ } \\
\text { Video Record) }\end{array}$ & $\begin{array}{l}\text { Interview } \\
\text { (Video Call) }\end{array}$ & $\begin{array}{c}\text { Closing } \\
\text { Meeting } \\
\text { (Video Live } \\
\text { streaming) }\end{array}$ \\
\hline 15 & PMPRB PB & $\mathrm{v}$ & $\mathrm{v}$ & - & $\mathrm{v}$ & $\mathrm{v}$ \\
\hline 16 & $\begin{array}{l}\text { Draft Review RPJMD } 2017- \\
2022\end{array}$ & $\mathrm{v}$ & $\mathrm{v}$ & v & $\mathrm{v}$ & $\mathrm{v}$ \\
\hline 17 & Draft Review RKPD 2021 & $\mathrm{v}$ & $\mathrm{v}$ & $\mathrm{v}$ & $\mathrm{v}$ & $\mathrm{v}$ \\
\hline 18 & $\begin{array}{l}\text { Monitoring Pelaksanaan } \\
\text { Renaksi Pencegahan } \\
\text { Korupsi TW II }\end{array}$ & $\mathrm{v}$ & $\mathrm{v}$ & $\mathrm{v}$ & $\mathrm{v}$ & v \\
\hline 19 & Review RKA APBD P 2020 & v & $\mathrm{v}$ & - & v & $\mathrm{v}$ \\
\hline 20 & Evaluasi SAKIP SKPD & $\mathrm{v}$ & $\mathrm{v}$ & - & $\mathrm{v}$ & $\mathrm{v}$ \\
\hline 21 & $\begin{array}{l}\text { Review PBJ dan Serapan } \\
\text { Anggaran Triwulan II }\end{array}$ & $\mathrm{v}$ & $\mathrm{v}$ & - & $\mathrm{v}$ & $\mathrm{v}$ \\
\hline 22 & Evaluasi LKIP Kab/Kota & $\mathrm{v}$ & $\mathrm{v}$ & - & $\mathrm{v}$ & $\mathrm{v}$ \\
\hline 23 & $\begin{array}{l}\text { Evaluasi Implementasi } \\
\text { SPIP OPD }\end{array}$ & $\mathrm{v}$ & $\mathrm{v}$ & - & v & $\mathrm{v}$ \\
\hline 24 & EKPPD & $\mathrm{v}$ & $\mathrm{v}$ & - & $\mathrm{v}$ & $\mathrm{v}$ \\
\hline 25 & $\begin{array}{l}\text { Pemeriksaan Akhir } \\
\text { Masa Jabatan Bupati } \\
\text { Pegunungan (9 Kab) }\end{array}$ & $\mathrm{v}$ & $\mathrm{v}$ & - & $\mathrm{v}$ & $\mathrm{v}$ \\
\hline 26 & $\begin{array}{l}\text { Review PBJ dan Serapan } \\
\text { Anggaran Triwulan III }\end{array}$ & $\mathrm{v}$ & $\mathrm{v}$ & - & $\mathrm{v}$ & $\mathrm{v}$ \\
\hline 27 & $\begin{array}{l}\text { Monitoring Pelaksanaan } \\
\text { Renaksi Pencegahan } \\
\text { Korupsi TW III }\end{array}$ & $\mathrm{v}$ & $\mathrm{v}$ & - & $\mathrm{v}$ & $\mathrm{v}$ \\
\hline 28 & $\begin{array}{l}\text { Pemeriksaan regular/ } \\
\text { kinerja Semester II }\end{array}$ & $\mathrm{v}$ & v & $\mathrm{v}$ & $\mathrm{v}$ & v \\
\hline 29 & $\begin{array}{l}\text { Review PBJ dan Serapan } \\
\text { Anggaran Triwulan IV }\end{array}$ & $\mathrm{v}$ & $\mathrm{v}$ & - & $\mathrm{v}$ & v \\
\hline 30 & $\begin{array}{l}\text { Monitoring Pelaksanaan } \\
\text { Renaksi Pencegahan } \\
\text { Korupsi TW IV }\end{array}$ & $\mathrm{v}$ & $\mathrm{v}$ & - & $\mathrm{v}$ & $\mathrm{v}$ \\
\hline 31 & Sosialisasi SPIP OPD & - & - & - & - & - \\
\hline 32 & Review RKA APBD 2021 & $\mathrm{v}$ & $\mathrm{v}$ & - & $\mathrm{v}$ & $\mathrm{v}$ \\
\hline 33 & $\begin{array}{l}\text { Penanganan Pengaduan } \\
\text { Masyarakat }\end{array}$ & $\mathrm{v}$ & $\mathrm{v}$ & $\mathrm{v}$ & $\mathrm{v}$ & $\mathrm{v}$ \\
\hline 34 & Optimalisasi Pajak Daerah & $\mathrm{v}$ & $\mathrm{v}$ & $\mathrm{v}$ & $\mathrm{v}$ & v \\
\hline 35 & Whistle Blowing System & - & - & - & - & - \\
\hline 36 & Evaluasi Kinerja BUMD & $\mathrm{v}$ & $\mathrm{v}$ & $\mathrm{v}$ & $\mathrm{v}$ & v \\
\hline 37 & $\begin{array}{l}\text { Audit Tujuan Tertentu } \\
\text { Permintaan Pimpinan }\end{array}$ & $\mathrm{v}$ & $\mathrm{v}$ & $\mathrm{v}$ & $\mathrm{v}$ & $\mathrm{v}$ \\
\hline 38 & $\begin{array}{l}\text { Audit Pelanggaran Kode } \\
\text { Etik ASN }\end{array}$ & v & $\mathrm{v}$ & - & $\mathrm{v}$ & $\mathrm{v}$ \\
\hline 39 & Audit Investigatif & v & $\mathrm{v}$ & v & $\mathrm{v}$ & $\mathrm{v}$ \\
\hline
\end{tabular}

Keterangan: (v) bisa dilaksanakan (-) tidak bisa dilaksanakan 
Berdasarkan uaraian di atas, disusun suatu prosedur pelaksanaan audit yang dapat diterapkan oleh auditor Inspektorat pada tiap tahapan audit dengan menggunakan metode remote audit yang dikembangkan oleh IIA (2020).

\section{Pra Audit}

Tim audit dan auditee menyepakati media teleconference yang akan digunakan pada saat entry meeting, wawancara, kunjungan lapangan dan closing meeting. Media yang dapat digunakan antara lain Google Meet, Zoom, Webex, Microsoft Team dan lain-lain. Beberapa hari sebelum pelaksanaan remote audit, tim audit dan auditee melakukan trial audit melalui media/perangkat teknologi informasi baik untuk teleconference, tinjauan lapangan maupun proses wawancara.

\section{Entry Meeting}

a. Tim audit dan auditee melaksanakan entry meeting menggunakan media teleconference pada waktu dan jam yang telah ditentukan

b. Tim audit memaparkan tujuan audit, susunan tim audit, jadwal, metode audit, keterbatasan audit dan lainnya

c. Tim audit dan auditee menyepakati media pengiriman data dan dokumen pada saat audit menggunakan google form, e-mail atau WhatsApp

d. Tim audit dan auditee membuat perjanjian kerahasiaan data dan dokumen (nondisclosure agreement)

e. Prosesentrymeeting didokumentasikan dalam bentuk screenshot, rekaman proses dan notulensi.

3. Kajian Dokumen

a. Tim audit meminta auditee menyiapkan data dan dokumen yang diperlukan dalam bentuk softcopy

b. Auditee mengirimkan data dan dokumen dengan cara upload ke media pengiriman yang telah disepakati

c. Tim audit melakukan verifikasi data dan dokumen

d. Tim audit melakukan data and document review

e. Tim audit membuat pokok-pokok hasil pemeriksaan atau kesimpulan awal hasil audit untuk dikomunikasikan kembali kepada auditee.

4. Kunjungan Lapangan

a. Kunjungan lapangan dilakukan untuk kegiatan audit yang memerlukan pemeriksaan fisik, misalnya audit barang jasa

b. Kunjungan lapangan dilakukan secara virtual melalui video live streaming

c. Apabila terdapat kondisi tertentu tidak dapat dilakukannya kunjungan secara virtual maupun adanya temuan material dalam audit jarak jauh dan membutuhkan pembuktian ke lapangan untuk memperoleh keyakinan yang memadai atas temuan tersebut, maka bisa dilakukan kunjungan lapangan secara langsung dengan tetap mematuhi protokol kesehatan.

5. Interview

a. Interview/wawancara dilakukan secara virtual melalui video live streaming

b. Tim audit harus memastikan bahwa orang yang diwawancara adalah benar-benar orang yang akan dimintai keterangan dengan cara meminta menunjukan kartu identitas diri

c. Proses wawancara didokumentasikan dalam bentuk screenshot, rekaman proses dan notulensi.

6. Closing Meeting

a. Tim audit dan auditee melaksanakan closing meeting menggunakan teleconference pada waktu yang telah ditentukan

b. Tim audit menyampaikan pokok-pokok hasil audit

c. Tim audit dan auditee menandatangani berita acara kesepakatan penyelesaian hasil audit

d. Proses entry meeting didokumentasikan dalam bentuk screenshot, rekaman proses dan notulensi

\section{KESIMPULAN}

Kegiatan audit yang dilakukan oleh Inspektorat Daerah Provinsi Papua Barat dalam masa pandemi masih menggunakan model audit tradisional atau tatap muka yang beresiko 
pada pandemi COVID-19. Remote audit dapat menjadi audit alternatif yang dilaksanakan selama masa pandemi. Model remote audit dapat diterapkan dalam setiap tahapan audit baik dalam pra audit, entry meeting, document review, kunjungan lapangan, wawancara, dan closing meeting. Pelaksanaan remote audit memiliki kelebihan antara lain mengurangi biaya perjalanan, memperluas cakupan audit, pengumpulan data dan dokumen lebih cepat dan kekurangan antara lain pengamatan secara langsung tidak dapat tergantikan, menyulitkan hubungan dengan auditee, kurangnya interaksi personal membuka peluang terjadinya fraud. Hal yang harus dipersiapkan dalam pelaksanaan remote audit adalah kesiapan teknologi informasi dan keterampilan auditor dan auditee dalam menggunakan peralatan teknologi informasi.

\section{UCAPAN TERIMA KASIH}

Penulis mengucapkan terima kasih kepada Inspektur Daerah Provinsi Papua Barat yang telah membantu berlangsungnya kegiatan penelitian. Terima kasih juga kepada reviewer yang telah merevisi dan memberikan arahan perbaikan naskah tulisan ini. Terima kasih kepada Badan Penelitian dan Pengembangan Daerah Provinsi Papua Barat, pimpinan redaksi dan tim Jurnal Igya Ser Hanjop atas kesempatan untuk menerbitkan naskah ini.

\section{Daftar Pustaka}

Castka, P., Searcy, C., \& Fischer, S. (2020). Technology-enhanced Auditing in Voluntary Sustainability Standards: The Impact of COVID-19. Sustainability, 12(11), 1-24. https://doi.org/10.3390/ su12114740
Efendi, A. (2020). Mekanisme Audit Kinerja Berbasis Teknologi Informatika Pada Masa Pandemi COVID-19 dan Pengaruhnya Terhadap Proses Pendiidkan dan Pelatihan Jabatan Fungsional Auditor (JFA) Aparat Pengawas Internal Pemerintah. Prosiding Seminar Nasional Pascasarjana Universitas Negeri Jakarta.

Iskandar, L. (2020). Remote Audit: Alasan, Syarat dan Pelaksanaannya. Katigaku.Top.

ISO. (2020). ISO 9001 Auditing Practices Group.

Litzenberg, R., \& Ramirez, C. F. (2020). Proses Audit Jarak Jauh Selama dan Setelah COVID-19: Implikasi Jangka Pendek dan Panjang.

Maudica, S. B., Denny, H. M., \& Kurniawan, B. (2020). Tantangan dan Hambatan proses Audit SMK 3 di Sebuah Perusahaan Galangan Kapal di Era Pandemi COVID-19. Jurnal Kesehatan Masyarakat, 8(5), 609 613.

Moleong, L. J. (1989). Metodologi penelitian kualitatif. PT. Remaja Rosdakarya.

Nazir, M. (2003). Metode Penelitian. Ghalia Indonesia.

Setianto, H. (2020). Remote Auditing dan Agility: Kiat Auditor Menavigasi Pandemi. Indonesia Risk Management Professional Association.

Tanudiredja, I., Nugroho, A., Sulistiyanto, B., Andria, B., Martani, D., Fahmi, Tomo, H., Haswir, I., Siahaan, P. F. T. H., Nugroho, R. T., Sriyanto, Tanggara, S., \& Nugroho, Z. (2020). Respons Auditor atas Pandemi Covid-19: Terhadap Laporan Keuangan, Prosedur Audit, dan Pertimbangan Praktis Penunjang Kualitas Audit (Technical Newsflash April 2020).

WHO. (2020). WHO Coronavirus (COVID-19) Dashboard. Who.Int. 